\title{
Problem odpowiedzialności odszkodowawczej państw za szkody środowiskowe, w tym klimatyczne
}

\author{
Wyrok Międzynarodowego Trybunału Sprawiedliwości w sprawie Certain \\ Activities Carried Out by Nicaragua in the Border Area (Costa Rica v. Nicaragua)
}

W przypadku ustalania wysokości odszkodowania za szkody środowiskowe, ocena opierać powinna się na kompleksowym oszacowaniu wartości utraconych, w wyniku bezprawnego działania państwa, usług ekosystemowych, uwzględniając ich wartość, czas potrzebny do ich odtworzenia oraz ich stopniowy przyrost wraz z przywracaniem środowiska do stanu sprzed naruszenia.

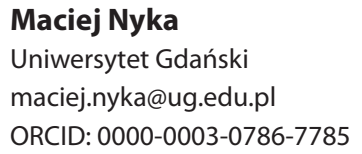

https://doi.org/10.26881/gsp.2021.3.12

\section{Glosa}

Odpowiedzialność odszkodowawcza państw w obszarze szkód spowodowanych zmianami klimatu pozostaje jednym z tych obszarów prawa międzynarodowego, który jak do tej pory nie doczekał się kompleksowego uregulowania. Zastosowanie wynikających z prawa zwyczajowego mechanizmów prawnomiędzynarodowej odpowiedzialności państw $w$ odniesieniu do szkód klimatycznych stanowić może swoiste wyzwanie. Podjął je Międzynarodowy Trybunał Sprawiedliwości w analizowanym orzeczeniu', odnosząc się w sposób ogólny do zagadnień odszkodowawczych w zakresie szkód w środowisku, w tym szkód w obszarze zmniejszania zdolności ekosystemów do dostarczania usług ekosystemowych w obszarze sekwestracji $\mathrm{CO}_{2}$. Jakkolwiek samo orzeczenie dotyczy generalnie zagadnień kompensacji za szkody środowiskowe, to mechanizmy w nim zaprezentowane będzie można wykorzystać $w$ realizacji roszczeń odszkodowawczych w obszarze zmian klimatu. Trybunał, dokonując oceny war-

\footnotetext{
1 Wyrok Międzynarodowego Trybunału Sprawiedliwości w sprawie Certain Activities Carried Out by Nicaragua in the Border Area (Costa Rica v. Nicaragua), Compensation, Judgment, I.C.J. Reports 2018, s. 15.
} 
tości szkód środowiskowych wyrządzonych przez nielegalną działalność Nikaragui, uwzględnił w tej wycenie także problem szkód klimatycznych.

Międzynarodowy Trybunał Sprawiedliwości (MTS) niezwykle rzadko wypowiadał się w kwestiach dotyczących szacowania wysokości odszkodowań. Wśród trzech spraw, w których MTS ustosunkowywał się do tego zagadnienia, tylko jedna odnosiła się do problemu odszkodowań za szkody środowiskowe. Rozstrzygnięcie w tej sprawie zapadło na początku 2018 r. i wydaje się wskazywać na prawdopodobny sposób szacowania wysokości odszkodowania, który mógłby być zastosowany w odniesieniu do szkód klimatycznych. W glosowanej sprawie Costa Rica vs Nicaragua, dotyczącej odszkodowania za bezprawną ingerencję w bieg cieków wodnych, MTS podtrzymał wynikający z dotychczasowego orzecznictwa obowiązek naprawienia szkody w formie odszkodowania. Już w przywołanej powyżej sprawie Fabryki w Chorzowie, Stały Trybunał Sprawiedliwości Międzynarodowej wskazał na fakt, że odszkodowanie powinno usunąć wszystkie skutki nielegalnego działania². Zasada pełnego zadośćuczynienia za szkodę w środowisku została zidentyfikowana przez MTS w sprawie Pulp Mills. Z jednej strony Trybunał uznał w nim możliwość naprawy szkody poprzez wypłatę rekompensaty $^{3}$. Z drugiej jednak strony - w tym samym orzeczeniu trybunał zastrzegł, że w tego typu sprawach rekompensata nie powinna mieć charakteru punitywnego. Zasada pełnej rekompensaty szkody w kontekście szkód klimatycznych podlegać może istotnym ograniczeniom, które uzasadnione mogą być specyfiką i rozmiarami szkód klimatycznych ${ }^{4}$, ale także właściwościami leżącymi po stronie państwa, wobec którego obowiązek rekompensaty został ustalony ${ }^{5}$.

Kontekst historyczny analizowanego sporu dotyczył konfliktu terytorialnego pomiędzy Nikaraguą a Kostaryką na obszarze ujścia rzeki San Juan. Spór ciągnie się wstecz do lat 50. XIX w., kiedy to między tymi dwoma państwami doszło do zawarcia traktatu granicznego w 1858 r. Granica na spornym terenie przebiega wzdłuż rozgraniczającej te dwa państwa rzeki, co jednocześnie daje Nikaragui dominium i imperium nad wodami rzeki San Juan, i co jednocześnie potwierdza prawa Nikaragui w zakresie swobody nawigacji na wodach rzeki na potrzeby handlu ${ }^{6}$. Przedmiotowy traktat i jego interpretacja była przedmiotem arbitrażu prowadzonego w latach 1886-1888 przez prezydenta USA Grovera Clevelanda, który potwierdził podstawowe postanowienia traktatu z 1858 r., doprecyzowując m.in. warunki, na jakich Nikaragua może prowadzić prace nad utrzymaniem dróg wodnych na rzece San Juan, a także instrumenty, w ramach których Kostaryka może przeciwstawiać się zmianom przebiegu nurtu rzeki w wyniku działań podejmowanych przez Nikaraguę. Wśród nich konieczność uzyskania zgody Kostaryki na budowę kanałów łączących rzekę z morzem, w szczególności w sytuacji gdy „budowa takiego kanału wiązałaby się ze szkodą w prawach

1928 P.C.I.J Series A No. 17, s. 47.

3 Pulp Mills on the River Uruguay ICJ Rep. 2010 (I) p. 103 i 104 par. 273.

4 B. Mayer, Climate Change Reparations and the Law and Practice of State Responsibility, Asian Journal of International Law 2016, vol. 7, s. 203

5 Ibidem.

6 Art. VI Traktatu z 1858 r. 
naturalnych Kostaryki"7 . W 1896 r. Kostaryka i Nikaragua zawarły Konwencję demarkacyjną Pacheco-Matus, a działające na jej mocy komisje demarkacyjne zakończyły swoje prace w $1900 \mathrm{r}$.

W czasach współczesnych spór rozgorzał na nowo w latach 80. XX w. Spór w tym zakresie trafił pod rozstrzygnięcie Międzynarodowego Trybunału Sprawiedliwości w 2005 r. a w 2009 r. MTS wydał orzeczenie m.in. potwierdzające prawa Kostaryki do nawigacyjnego korzystania z wód rzeki San Juan, a Nikaragui prawo do kontroli nad wodami tej rzeki ${ }^{8}$. W 2010 r. Nikaragua rozpoczęła prace w zakresie pogłębiania rzeki San Juan u jej ujścia. Zakres tych prac był kontestowany przez Kostarykę, która zarzucała Nikaragui wykonanie sztucznych kanałów (caños) na terytorium Kostaryki - zdaniem Nikaragui doszło jedynie do pogłębienia już istniejących połączeń znajdujących się na terytorium Nikaragui. Nikaragua wysłała także na sporne terytorium oddziały wojskowe celem ochrony realizowanych tam prac. Efektem powyższych działań, a także kontestowania przez Nikaraguę legalności robót drogowych realizowanych przez Kostarykę wzdłuż biegu rzeki San Juan do Międzynarodowego Trybunału Sprawiedliwości wpłynęły dwie skargi. Jedna dotyczyła zagadnień związanych z naruszeniem suwerenności terytorialnej w zakresie przeprowadzania robót na rzece San Juan przez Nikaraguę (18 listopada 2010 r.), a druga - problemów związanych z transgranicznymi oddziaływaniami na środowisko, związanymi z budową drogi przez Kostarykę (22 grudnia 2011 r.). Trybunał podjął decyzję o połączeniu tych spraw do łącznego rozpoznania ${ }^{9}$, wydając 16 grudnia 2015 r. wyrok. W wyroku tym MTS z jednej strony uznał, że Nikaragua nie udowodniła wystąpienia szkody w środowisku o charakterze szkody transgranicznej, a także nie była w stanie udowodnić wystąpienia naruszeń przez to państwo przywoływanych aktów prawa międzynarodowego ${ }^{10}$. Z drugiej strony w wyroku trybunał potwierdził zarzucany Nikaragui przez Kostarykę fakt naruszenia jej suwerenności poprzez prowadzenie prac na jej terytorium związanych z budową caño, a także poprzez obecność wojskową na tym terytorium. Trybunał uznał Nikaraguę za winną tych działań i potwierdził obowiązek Nikaragui w zakresie stosownych reparacji na rzecz Kostaryki ${ }^{11}$.

W związku z brakiem porozumienia między stronami co do formy i wysokości reparacji w terminie 12 miesięcy, wyznaczonym przez trybunał w wyroku w sprawie Kostaryka vs Nikaragua. Kostaryka zwróciła się ponownie do MTS w styczniu 2017 r. o określenie wysokości odszkodowania należnego Kostaryce za działania będące przedmiotem sporu zakończonego wyrokiem z 16 grudnia 2015 r. Przystępując, co zostało już wspomniane powyżej, po raz pierwszy do określenia wysokości odszkodowania za szkody środowiskowe, MTS oparł się na - wynikających z orzecznictwa

\footnotetext{
Par. 3 ust. 11, arbitraż z 1888 r.

Costa Rica vs Nicaragua ICJ Reports 2009, p. 213.

9 Certain Activities carried out by Nicaragua in the Border Area (Costa Rica v. Nicaragua) Construction of a Road.

${ }^{\text {in }}$ Costa Rica along the San Juan River (Nicaragua v. Costa Rica), [2015] ICJ Rep. A/71/4.

10 Par. 217 i 220 wyroku.

11 Par. 92 i 93 wyroku.
} 
sądów i trybunałów międzynarodowych - zasadach naprawienia szkód o charakterze materialnym. Po pierwsze, trybunał potwierdził, że reparacje powinny, na ile jest to możliwe, usunąć wszystkie skutki nielegalnego działania państwa i przywrócić stan analogiczny do sytuacji, jak gdyby do bezprawnych działań nie doszło ${ }^{12}$. Po drugie, odwołał się do zasady pełnego odszkodowania za bezprawne działania, która wynika z orzeczeń Gwinea vs Kongo ${ }^{13}$, Meksyk vs USA ${ }^{14}$, jak i z jednego z najistotniejszych dla rozwoju międzynarodowego prawa środowiska orzeczenia w sprawie Gabčíkovo-Nagymaros ${ }^{15}$. Międzynarodowy Trybunał Sprawiedliwości potwierdził także fakt, że odszkodowanie może być właściwą formą reparacji, w szczególności w sytuacji, gdy restitutio in integrum jest niemożliwe lub utrudnione. W tym zakresie Trybunał odwołał się do sprawy Pulp Mills ${ }^{16}$, gdzie ta forma rekompensaty została przyjęta w sprawie dotyczącej zagadnień środowiskowych. W literaturze podnosi się często, że zasada pełnej rekompensaty szkody w kontekście szkód klimatycznych podlegać może istotnym ograniczeniom ${ }^{17}$, które uzasadnione mogą być specyfiką i rozmiarami szkód klimatycznych $^{18}$, ale także właściwościami leżącymi po stronie państwa, wobec którego obowiązek rekompensaty został ustalony ${ }^{19}$.

Przystępując do wywodu dotyczącego zagadnienia wysokości odszkodowania, trybunał słusznie stwierdził, że w sprawach dotyczących szkód środowiskowych (w tym także klimatycznych - przyp. M.N.) występować mogą istotne problemy związane z wykazaniem związku przyczynowego pomiędzy skutkiem środowiskowym a bezprawnym działaniem ${ }^{20}$. W doktrynie słusznie podnosi się, że zagadnienie mierzalności szkód powstałych w środowisku, wskutek zmian klimatu jest jednym z bardziej interesujących problemów związanych z kompensacją tego typu szkód, a ich prawna ocena jest uzależniona do ustaleń nauk przyrodniczych i ekonomicznych w zakresie skutków zmian klimatu na środowisko Ziemi ${ }^{21}$. Dotychczasowa praktyka sądów i trybunałów międzynarodowych wskazuje, że większość procesów wyceny szkód w środowisku dotyczy małych i niekatastrofalnych zmian w stanie poszczególnych elementów środowiska ${ }^{22}$. Szkody w skali globalnej, a jako takie ujmować można szkody klimatyczne, pozostają póki co poza materią orzeczniczą tych sądów. Pamiętać bowiem trzeba, że zmiany klimatu są wynikiem sumy działań podejmowanych w ramach wszystkich

12 Par. 29 odwołujący się do orzeczenia Stałego Trybunału Międzynarodowego w sprawie Chorzów.

Republic of Guinea v. Democratic Republic of the Congo, Merits, Judgment, I.C.J. Reports 2010 (II), p. 691, para. 161.

14 Avena and Other Mexican Nationals (Mexico v. United States of America), Judgment, I.C.J. Reports 2004 (I), p. 59, para. 119.

15 Gabčíkovo-Nagymaros Project (Hungary/Slovakia), Judgment, I.C.J. Reports 1997, p. 80, para. 150.

16 Pulp Mills on the River Uruguay (Argentina v. Uruguay), Judgment, I.C.J. Reports 2010 (I), pp. 103104, para. 273.

17 J. Ciechanowicz-McLean, Prawo ochrony klimatu, Warszawa 2016, s. 161 i n.

18 B. Mayer, Climate Change Reparations and the Law and Practice of State Responsibility, Asian Journal of International Law 2016, vol. 7, s. 203.

19 Ibidem.

20 Par. 34.

21 J. Ciechanowicz-McLean, Prawo ochrony..., s. 168.

22 Ibidem, s. 167. 
jurysdykcji kumulujących się na przestrzeni dekad w zasadzie od czasów rewolucji przemysłowej. Co więcej, emisje antropogeniczne współistnieją z emisjami wynikającymi z procesów naturalnych, a ich oddzielenie jest możliwe tylko umownie i w sposób nieprecyzyjny. Pamiętać także trzeba, że emisje antropogeniczne w przeważającej części nie wynikają z działalności państw per se, tylko podmiotów działających na ich terytorium. Jednocześnie odpowiedzialność prawnomiędzynarodowa, w tym odpowiedzialność w obszarze ochrony środowiska lub prawa klimatycznego powstać może zarówno na skutek podejmowanych przez państwo działań, jak i zaniechań ${ }^{23}$.

Kolejnym problemem i wyzwaniem może być fakt, że w przypadku opierania roszczeń o ogólne normy prawa międzynarodowego dotyczące odpowiedzialności, możliwość przypisania konkretnemu działaniu państwa konkretnej szkody jest niezwykle trudne ${ }^{24}$. Podobnie zresztą jak odróżnienie szkód wywołanych zjawiskami naturalnymi od szkód w istocie wywołanych tymi samymi zjawiskami, ale o większym natężeniu, częstotliwości występowania lub rozmiarach, będących skutkiem emisji antropogenicznych $^{25}$. Wynika to z faktu występowania w kontekście emisji efektu synergii i nielinearnego wpływu tych emisji na występowanie negatywnych skutków zmian klimatu $^{26}$. Problemem może się zatem stać wykazanie bezpośredniego i konkretnego wpływu działań lub zaniechań państwa na zmiany klimatu, a zwłaszcza na wynikające z nich szkody. Pamiętać bowiem trzeba, że art. 31 ust. 2 artykułów o odpowiedzialności państw za akty sprzeczne z prawem międzynarodowym, a w zasadzie komentarz do tego artykułu, wskazuje na wykluczenie szkód, w których przyczyna powstania jest zbyt odległa, a związek przyczynowy nie ma charakteru bezpośredniego ${ }^{27}$. Jednocześnie orzecznictwo sądów międzynarodowych wydaje się wskazywać coś zgoła innego. W sprawie Naulilaa Panel Arbitrażowy wskazał na możliwość przewidzenia nawet relatywnie odległych negatywnych konsekwencji ataku na kolonie Portugalii ${ }^{28}$. W wyroku w sprawie Korfu, trybunał za wystarczające uznał uprawdopodobnienie wystąpienia szkody $^{29}$ związanej z brakiem reakcji władz Albanii.

Międzynarodowy Trybunał Sprawiedliwości, odnosząc się do problemów związanych z zagadnieniami dowodowymi w postępowaniach dotyczących m.in. problemów zmian klimatu, wskazał, że w zgodnie z orzecznictwem trybnału, w uzasadnionych przypadkach braki w tym zakresie nie muszą oznaczać braku możliwości ubiegania się o odszkodowanie ${ }^{30}$.

23 M.M. Kenig-Witkowska, Międzynarodowe prawo środowiska. Wybrane zagadnienia systemowe, Warszawa 2011, s. 140.

24 Ibidem, s. 139

25 B. Mayer, Climate Change Reparations and the Law and Practice on State Responsibility , Asian Journal of International Law" 2017, vol. 7, s. 204.

26 M.M. Kenig-Witkowska Międzynarodowe prawo..., s. 139.

27 Komentarz do art. 31, pkt 10, Draft articles on Responsibility of States for Internationally Wrongful Acts, with commentaries.

28 The Naulilaa Case 2, R. Int'l Arb. Awards 1011 (1949).

29 ICJ Rep. 1949.

30 Trail Smelter case (United States, Canada), 16 April 1938 and 11 March 1941, United Nations, Reports of International Arbitral Awards (RIAA), Vol. III, p. 1920.; Ahmadou Sadio Diallo (Republic of Guinea v. Democratic Republic of the Congo), Compensation, Judgment, I.C.J. Reports 2012 (I), p. 337, para. 33. 
W analizowanej sprawie Kostaryka wystąpiła o odszkodowanie obejmujące dwie kategorie szkód. W ramach pierwszej kategorii Kostaryka ujęła szkody związane z pracami związanymi z przekopywaniem caño, których charakter był jednoznacznie środowiskowy. W tym obszarze Kostaryka zidentyfikowała aż 22 kategorie dóbr i usług środowiskowych, które zostały utracone, lub korzystanie z których zostało ograniczone w konsekwencji bezprawnych działań Nikaragui. Roszczenie odszkodowawcze odnosiło się jednak jedynie do sześciu z nich - zasobów drewna wyciętego w związku z pracami nad caño, innych zasobów naturalnych, a co najistotniejsze z punktu widzenia problematyki roszczeń odszkodowawczych w obszarze ochrony środowiska usług ekosystemowych, ubytek których nastąpił w wyniku działań Nikaragui. Wśród utraconych usług ekosystemowych Kostaryka wskazała - kluczową z punktu widzenia ochrony klimatu - regulację gazową (sekwestracja gazów cieplarnianych) ${ }^{31}$, poprawę jakości powietrza, przeciwdziałanie kataklizmom naturalnym, funkcje glebotwórcze oraz ograniczanie erozji, a także usługi w zakresie ochrony bioróżnorodności ${ }^{32}$. Straty w obszarze różnorodności biologicznej są o tyle istotne, że obszar prowadzonych prac objęty był ochroną w ramach Konwencji o obszarach wodno-błotnych mających znaczenie międzynarodowe, zwłaszcza jako środowisko życiowe ptactwa wodnego (tzw. konwencji ramsarskiej) ${ }^{33}$. W istocie większość strat w obszarze usług ekosystemowych była następstwem wycinki realizowanej na potrzeby prac ziemnych, obejmujących stosunkowo nieduży obszar 6,19 ha. W ramach drugiej kategorii, Kostaryka wystąpiła o odszkodowanie w zakresie monitorowania i działań podejmowanych bezpośrednio w związku z wystąpieniem szkody środowiskowej. Z uwagi na przedmiot niniejszej analizy, istotne znaczenie ma pierwsza wspomniana tutaj kategoria. Roszczenia Kostaryki w zakresie szkód środowiskowych opiewały na kwotę $2.880 .745,82$ dolarów USA.

W istocie, w analizowanej sprawie przyjęto trzy, a nawet cztery metody wyceny szkód środowiskowych. Po pierwsze, Kostaryka przyjęła metodę, którą nazywa metodą "podejścia ekosystemowego" - w oparciu o nią środowisko jest wyceniane w oparciu o dobra i usługi ekosystemowe, które tworzą ekosystemy. W odniesieniu do niektórych dóbr środowiskowych, możliwe było wskazanie konkretnej wartości rynkowej (np. drewno). W przypadku innych (np. zapobieganiu powodziom czy sekwestracja $\mathrm{CO}_{2}$ ) wartość ocenić można jedynie pośrednio. Takie podejście Kostaryki wraz z prawidłowo zidentyfikowanymi dobrami i usługami ekosystemowymi, które uległy zniszczeniu lub uszczupleniu, odzwierciedla realną wartość szkody środowiskowej.

Odmienną metodę wyceny szkód środowiskowych zaproponowała Nikaragua. Oparła się ona na koncepcji „kosztów zastępczych”, liczonych jako koszt zachowania innego podobnego obszaru na czas w którym wartość dóbr i usług ekosystemowych na obszarze objętym postępowaniem będzie się odbudowywać. Powołując się na tę

31 Par. 64 wyroku MTS w sprawie Costa Rica vs Nicaragua.

32 Par. 55.

33 Konwencja o obszarach wodno-błotnych mających znaczenie międzynarodowe, zwłaszcza jako środowisko życiowe ptactwa wodnego przyjęta 2 lutego 1972 w Ramsar (Dz. U. z 1978 r. Nr 7, poz. 24). 
metodę, Nikaragua wskazała, że jest ona zbliżona do metod przyjętych przez Komisję NZ, szacującą szkody środowiskowe w trakcie pierwszej wojny w Zatoce Perskiej.

Trybunał podjął decyzję, że przy szacowaniu wysokości odszkodowania stworzy swoją własną metodę, bazującą na wartych uwzględnienia elementach metod wyceny, zaprezentowanych przez strony sporu ${ }^{34}$. Zrobił to, bazując na podejściu ekosystemowym. W doktrynie funkcjonuje wiele różnych definicji usług ekosystemowych. Jedną z pierwszych sformułował w roku 1997 Robert Constanza z zespołem, stwierdzając, że na dobra i usługi środowiskowe składają się przepływy materii, energii i informacji z zasobów naturalnych, które wspólnie z dobrami i usługami wytworzonymi przez człowieka przyczyniają się do budowy jego dobrobytu ${ }^{35}$. W polskiej doktrynie Bazyli Poskrobko definiuje usługi ekosystemowe jako „walory, siły i procesy przyrodnicze, a także efekty ich istnienia i funkcjonowania, dostarczające pozamaterialnych „wartości" niezbędnych do życia i rozwoju ludzkości oraz przyczyniające się do przebiegu gospodarczych procesów wytwórczych, ale fizycznie w tych procesach nieuczestniczące ${ }^{\prime \prime 3}$.

Trybunał, dokonując wyceny dóbr i usług ekosystemowych utraconych w wyniku bezprawnych działań Nikaragui, skoncentrował się na wartości usług dostarczanych przez ekosystem jako całość oraz różnicy w ich wartości wynikłej ze szkód środowiskowych spowodowanych działaniami Nikaragui ${ }^{37}$. Wpierw identyfikował - dostępność jakich usług systemowych mogła ulec ograniczeniu w wyniku bezprawnych działań, a następnie dokonał oszacowania szkody odrębnie dla każdej z nich. Co więcej, MTS uwzględnił przy okazji szacowania uszczerbku w dostępności usług ekosystemowych nie tylko fakt, że usługi te mają szansę ulec odtworzeniu po upływie określonego okresu czasu, ale także to, że przywracanie dostępności tych usług następować będzie stopniowo, i tak samo rozciągnięta w czasie szkoda będzie się zmniejszać wraz z upływem czasu. Trybunał wskazał także, że szkoda będzie miała inny wymiar czasowy dla każdej z analizowanych kategorii usług ekosystemowych ${ }^{38}$. Kwestia długotrwałych, acz z biegiem czasu słabnących skutków dla usług ekosystemowych została także podniesiona w kontekście usług sekwestracyjnych $\mathrm{CO}_{2}$. Tutaj trybunał nie zgodził się z propozycją Nikaragui, że szkoda miała charakter jednorazowy, i również uwzględnił wieloletnią perspektywę czasową ocenianej szkody.

Dokonując wyceny szkód w dostępności poszczególnych usług ekosystemowych, MTS uwzględnił także fakt, że część obszaru objętego negatywnym oddziaływaniem Nikaragui stanowiła tzw. Obszar Ramsar, a więc obszar chroniony, wpisany na listę obszarów chronionych konwencji ramsarskiej. W ocenie trybunału, miało to znaczenie

\footnotetext{
34 Par. 52.

35 R. Costanza, R. d'Arge, R. de Groot et al., The Value of the World's Ecosystem Services and Natural Capital Nature 1997, vol. 387, s. 256.

36 B. Poskrobko Usługi środowiska jako kategoria ekonomii zrównoważonego rozwoju „„Ekonomia i Środowisko" 2010, nr 1, s. 20.

37 Wyrok MTS w sprawie Costa Rica vs Nicaragua, par. 78.

38 Ibidem, par. 82.
} 
przy wycenie szkód w usługach podtrzymujących bioróżnorodnośćc ${ }^{39}$. Dokonując podsumowania szacowanych szkód, trybunał odniósł się do wspomnianego już w tym artykule orzeczenia w sprawie Trail Smelter oraz do sprawy Ahmadu Sadio Dallo ${ }^{40}$, stwierdzając, że brak możliwości dokładnego oszacowania szkody nie powinien stanowić przeszkody w jej kompensacji, a w sytuacji takiej rozstrzygnięcie opierać się może na słusznych szacunkach trybunału ${ }^{41}$.

Międzynarodowy Trybunał Sprawiedliwości, dokonując szacunku wartości odszkodowania, odrzucił sugerowaną przez Nikaraguę kwotę 309 dolarów USA rocznie za 1 ha. Jest to kwota, którą Kostaryka subsydiuje lokalnych właścicieli ziemskich jako rekompensatę za utracone korzyści finansowe, związane z koniecznością ochrony obszarów będących przedmiotem sporu. Nie sposób nie zgodzić się z opinią trybunału, że kwoty te służą zupełnie innym celom niż odszkodowanie będące przedmiotem postępowania. Po pierwsze, odszkodowanie to bowiem dotyczy kosztów alternatywnych rezygnacji z pewnych sposobów korzystania z tego obszaru; a po drugie, co nie zostało wspomniane przez Trybunał, właściciele ziemscy otrzymujący subsydium, korzystają z całego szeregu usług ekosystemowych, których ochronie wspomniany mechanizm finansowy ma służyć. Za wartościowe należy przyjąć także podejście Trybunału, który stwierdził, że szkodę środowiskową należy wyceniać z perspektywy ekosystemu jako całości, dokonując ogólne oceny szkód w obszarze dóbr i usług środowiskowych ${ }^{42}$. Na uznanie zasługuje także podkreślenie przez trybunał, że wpływ na wysokość odszkodowania powinien mieć także fakt, że szkoda została wyrządzona na obszarach przyrodniczo wartościowych, objętych ochroną konwencji ramsarskiej ${ }^{43}$.

W świetle powyższych założeń przyjętych przez MTS przy szacowaniu szkody środowiskowej, dziwić może uznanie, że wartość utraconych dóbr i usług środowiskowych została przez trybunał oszacowana na 120 tys. dolarów za cały okres ich odtwarzania. W swoim orzeczeniu MTS nie uzasadnił w sposób adekwatny sposobu wyceny. Odwołuje się jednak obszernie do trzeciej, alternatywnej metody wyceny zaprezentowanej przez Nikaraguę, którą nazywa "poprawioną analizą" (corrected analysis) ${ }^{44}$. Co ciekawe, robi to pomimo faktu, że wpierw poddaje tą metodę krytyce ${ }^{45}$. Deklarowane holistyczne podejście trybunału, dotyczące wyceny dóbr i usług środowiskowych utraconych w wyniku szkody wyrządzonej przez Nikaraguę, daje paradoksalnie efekt pod postacią ograniczenia wysokości wyceny tych usług do poziomu kilku procent wyceny dokonanej przez Kostarykę w odniesieniu do jedynie wybranych dóbr i usług ekosystemowych.

39 Ibidem, par. 80.

40 Guinea v Democratic Republic of the Congo, Judgment, Preliminary Objections, ICJ GL No 103.

41 Wyrok MTS w sprawie Costa Rica vs Nicaragua, par. 86.

42 Ibidem, par. 78.

43 Ibidem, par. 80

44 lbidem, par. 86.

45 Ibidem, par. 85. 


\section{Wnioski}

Podsumowując, uznać trzeba, że w analizowanym orzeczeniu Międzynarodowy Trybunał Sprawiedliwości wskazał pewne istotne ogólne założenia, jakimi należy posługiwać się, dokonując wyceny szkód środowiskowych. Warte odnotowania jest oparcie metody szacowania szkody na - nie do końca przejrzyście zastosowanej (przynajmniej jeśli chodzi o kwoty) - wycenie dóbr i usług ekosystemowych, czyli na podejściu ekosystemowym. Szkodę środowiskową zaś, w rozumieniu trybunału, stanowi brak lub ograniczenie możliwości dostarczania przez poszczególne elementy ekosystemu dóbr i usług.

Warto także pozytywnie ocenić przyjęcie przez Trybunał elastycznego podejścia do wyceny wysokości odszkodowania, zagadnienia dowodów, jeśli chodzi o wysokość poniesionej szkody i kwestii związanych ze szczegółowymi elementami odnoszącymi się do ustalania związku przyczynowego pomiędzy nielegalnym działaniem a odszkodowaniem. Elastyczność tego typu wydaje się nieodzowna w sprawach dotyczących kwestii odszkodowawczych za szkody środowiskowe, w tym także za szkody klimatyczne.

Nie sposób jednak nie zauważyć istotnych braków, czy wprost błędów, jakich dopuścił się trybunał w swojej argumentacji.

W doktrynie, w komentarzach do analizowanego wyroku, podnosi się istotną kwestię dotyczącą tego, że wobec braku opisania szczegółowej metody wyceny dóbr i usług środowiskowych, wyrok ten ma ograniczoną możliwość, jeśli chodzi o wykorzystywanie go w innych rozstrzygnięciach ${ }^{46}$. Warto wskazać, że pomimo odwoływania się do formuły z orzeczenia w sprawie Chorzów, dotyczącej przywrócenia poszkodowanej strony do pozycji sprzed zaistniałej szkody, MTS poniechał skorzystania z jednego z podstawowych instrumentów wykorzystywanych przy analizie ryzyka środowiskowego zarówno w ujęciu krajowym, jak i międzynarodowym, a więc - z oceny oddziaływania na środowisko. Przeprowadzenie takiej oceny dałoby wgląd w specjalistyczną wiedzę dotyczącą skutków działań Nikaragui ${ }^{47}$.

Trybunał w glosowanym wyroku w sposób niekonsekwentny wpierw identyfikuje listę ponad 20 dóbr i usług środowiskowych, które zostały utracone w wyniku działań Nikaragui, wskazuje na liczne okolicznościt, których wzięcie pod uwagę sugeruje wzrost wysokości utraconych usług ekosystemowych, tylko po to, żeby następnie uznać, że ich wycena zostanie zrealizowana łącznie, i to jeszcze w budzącej kontrowersje wysokości. Dokonuje tego bez odwołania do wiedzy eksperckiej, do czego prawo daje mu przecież art. 50 Statutu MTS ${ }^{48}$.

\footnotetext{
46 J. Rudall, Certain Activities Carried Out by Nicaragua in the Border Area. (Costa Rica v. Nicaragua). Compensation Owed by the Republic of Nicaragua to the Republic of Costa Rica, The American Journal of International Law 2018, vol. 112.

47 Ibidem, s. 292.

48 Statut Międzynarodowego Trybunału Sprawiedliwości (Dz. U. z 1947 r. Nr 23, poz. 90).
} 
W świetle powyższych uwag stwierdzić trzeba, że to pierwsze, ale z pewnością nie ostatnie orzeczenie MTS dotyczące wyceny szkód środowiskowych wskazuje pewne kierunki rozumowania, lecz nie daje precyzyjnych odpowiedzi dotyczących kwestii szczegółowych dotyczących tego typu rozstrzygnięć. Z pewnością braki te będą musiały być uzupełnione w dalszym orzecznictwie MTS.

\section{Literatura}

Ciechanowicz-McLean J., Prawo ochrony klimatu, Warszawa 2016.

Costanza R., R. d'Arge, R. de Groot, S. Farber, M. Grasso, B. Hannon, K. Limburg, S. Naeem, R. O'Neill, J. Paruelo, R. Raskin, P. Sutton, M. van den Bel, The Value of the World's Ecosystem Services and Natural Capital Nature 1997, vol. 387.

Kenig-Witkowska M.M., Międzynarodowe prawo środowiska. Wybrane zagadnienia systemowe, Warszawa 2011.

Draft articles on Responsibility of States for Internationally Wrongful Acts, with commentaries, komentarz do art. 31, punkt 10.

Mayer B., Climate Change Reparations and the Law and Practice of State Responsibility, Asian Journal of International Law 2016, vol. 7, p. 185-216.

Poskrobko B., Usługi środowiska jako kategoria ekonomii zrównoważonego rozwoju , „Ekonomia i Środowisko" 2010, nr 1.

Rudall J., Certain Activities Carried Out by Nicaragua in the Border Area. (Costa Rica v. Nicaragua). Compensation Owed by the Republic of Nicaragua to the Republic of Costa Rica, "The American Journal of International Law" 2018, vol. 112.

\section{Streszczenie}

Maciej Nyka

Problem odpowiedzialności odszkodowawczej państw za szkody środowiskowe, w tym klimatyczne

Autor poddaje analizie pierwszy w historii wyrok Międzynarodowego Trybunału Sprawiedliwości dotyczący szacowania wysokości odszkodowania za szkody środowiskowe. Autor analizuje go pod kątem możliwości realizacji roszczeń odszkodowawczych w odniesieniu do szkód klimatycznych. Autor co do zasady zgadza się z przyjętymi przez MTS zasadami, jednakże krytykuje część ustaleń faktycznych oraz wysokość zasądzonego odszkodowania.

Słowa kluczowe: prawo klimatu; odszkodowanie za szkody klimatyczne; prawo ochrony środowiska; szkoda klimatyczna. 


\section{Summary}

Maciej Nyka

Problem of States' Liability for Environmental Damages - Including Climate Change Damages

The Author analyses the unprecedented judgement of the International Court of Justice concerning the evaluation of compensation for environmental damages. The Author analyses the judgement from the perspective of applying the approach presented by the Court to claims concerning compensation for climate damages. The Author partly accepts the position of the Court, however, he criticizes some of the factual findings as well as the amount of the compensation.

Keywords: climate law; compensation for climate damages; environmental law; climate damage. 